between Pokrovskoye-Streshnievo and Khoroshevsky Serebrianny Bor in 1937. Among the buildings already under construction on the site are the Epidemiological and Microbiological Institutes of the State Health Inspection Department, veterinary stations for horses, laboratories where horse serums and vaccines will be prepared and a department to house small animals for experimental purposes. The Traumatological Institute will have a children's clinic for the study of common injuries, especially those sustained in street accidents. An Orthopædic Department, a special jaw clinic, and a large department for mechanical therapy are also included in the plans for this Institute. The buildings of the All-Union Institute of Experimental Medicine will be commenced next spring and will occupy a site of 1,000 acres. The Institute will also serve as a postgraduate medical school.

\section{Gold Coast Surveys}

THE report of the Gold Coast Survey for 1935-36 (Accra, 1936. 1s.), while recording a steady development of useful work, lays stress on the want of resources for the adequate survey of the Colony. It is the difficulty which most colonial surveys have to face and represents the results of a short-sighted policy. The greater part of the Northern Territories is completely unmapped. In the south and in Ashanti only part of the primary triangulation is completed. Development of prospective mining areas is liable to be checked by want of geological surveys, which cannot be carried out without a topographical map. Air surveys have been considered, but the two difficulties are much densely forested country and a lack of fixed points from which to work. Another urgent matter is the extension of geodetic levelling. An old network of levels exists, but requires checking with modern standards of accuracy.

\section{Steam Locomotives and Small Craft}

From the Association of Engineering and Shipbuilding Draughtsmen come two pamphlets- "Steam Locomotive Design" by D. Patrick (London : The Draughtsman Publishing Co., Ltd. 4s.) and "Small Craft Types" by John A. Mavor (ibid. 3s.). The former discusses the design of component parts and includes all the more important details, except the boiler and its attachments. An earlier publication dealt with preliminary design, and the present work carries it on from the point at which wheel arrangements, cylinder sizes, etc., have been determined, and, with the above exception, practically completes the subject in relation to engines of normal design. In his pamphlet, Mr. Mavor gives general descriptions and data of the humbler types of craft including trawlers, tugs, lightships, dredgers, etc., and explains the special features and working conditions peculiar to each. The main outlines of their design are presented, and the methods are indicated by which the forms of structure, machinery and fittings are adapted to meet the different conditions under which these ships are navigated and operated.

\section{Catalogue of Fishes}

GÜNTHER's "Catalogue of Fishes in the British Museum" was issued in 1859-70, and has long been out of print. The great work of Cuvier and Valenciennes was never finished, and Günther's is the only complete systematic monograph of the group in existence, and is therefore indispensable to ichthyologists. The time that has elapsed since Günther prepared his catalogue has seen the collection on which it was based quadrupled, and the number of known species about doubled; these factors alone would make the preparation of a revised edition a heavy task, and if to them be added the necessary study of the numerous systematic monographs and faunistic memoirs that have appeared since the catalogue was published, it is clearly one that no man could hope to complete. In these circumstances, to meet an evident demand, the Trustees of the British Museum have decided to reissue the "Catalogue of Fishes" in its original form, and at the original price of $£ 39 s$. for the complete work in eight volumes. It will be available early in 1937 .

\section{Pathology and Bacteriology at Leeds}

THE annual report of the Department of Pathology and Bacteriology of the University of Leeds, recently issued, by Profs. M. J. Stewart and J. W. McLeod, gives an account of the teaching and research work and routine examinations conducted in the Depart. ment during 1935. The research work includes the systematic investigation of industrial pulmonary affections, studies on new growths, and an investi. gation of types of the diphtheria bacillus present in six thousand cases of diphtheria occurring in England, Scotland, Ireland and Germany. Prof. R. D. Passey contributes a summary of researches carried out in the Department of Experimental Pathology and Cancer Research.

\section{The Indian Earthworm}

Ten years after its first appearance, Prof. K. N. Bahl's monograph on Pheretima, the Indian earth. worm, has passed into a second edition (Lucknow : Lucknow Publishing House, 1936). That is sufficient to indicate that the work has found its place as a guide to teachers and students of Indian zoology, as one of the excellent series of Zoological Memoirs on Indian Animal Types, projected and edited by Prof. Bahl. The first edition was favourably reviewed in NATURE $(119,557 ; 1927)$, and the second is even better in that the author has revised the text and incorporated new information and illustrations.

\section{Birds of Agricultural Importance}

The Ministry of Agriculture and Fisheries has issued, bound in an attractive folder, a group of twenty-three "Advisory Leaflets", dealing with the agricultural activities of common British birds. Several of these have already been referred to in Nature. The price is $1 s .6 d$. net. 